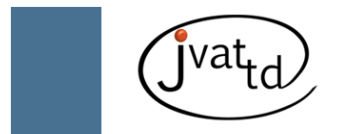

\title{
Molecular techniques for the study and diagnosis of parasite infection
}

Tavares RG (1, 2), Staggemeier R (3), Borges ALP (3), Rodrigues MT (3), Castelan LA (3), Vasconcelos J (3), Anschau ME (3), Spalding SM (4)

(1) Institute of Health Sciences, Biomedicine, Feevale University, Novo Hamburgo, Rio Grande do Sul State, Brazil; (2) Department of Diagnostic Methods, Federal University of Health Sciences of Porto Alegre, Porto Alegre, Rio Grande do Sul State, Brazil; (3) Graduate Program in Clinical Microbiology, Feevale University, Novo Hamburgo, Rio Grande do Sul State, Brazil; (4) Department of Parasitology, Federal University of Rio Grande do Sul, Porto Alegre, Rio Grande do Sul State, Brazil.

\begin{abstract}
In parasitology, routine laboratory diagnosis involves conventional methods, such as optical microscopy, used for the morphological identification of parasites. Currently, molecular biology techniques are increasingly used to diagnose parasite structures in order to enhance the identification and characterization of parasites. The objective of the present study was to review the main current and new diagnostic techniques for confirmation of parasite infections, namely: polymerase chain reaction (PCR), real-time polymerase chain reaction (RT-PCR), loop-mediated isothermal amplification (LAMP), Luminex XMAP, random amplified polymorphic DNA (RAPD), amplified fragment length polymorphism (AFLP), and restriction fragment length polymorphism (RFLP), in addition to microsatellites. Molecular assays have comprehensively assisted in the diagnosis, treatment and epidemiological studies of parasitic diseases that affect people worldwide, helping to control parasitic disease mortality.
\end{abstract}

Key words: parasite infection, diagnosis, molecular techniques, molecular epidemiology.

\section{INTRODUCTION}

In parasitology, routine laboratory diagnosis involves conventional methods, such as optical microscopy, used for the morphological identification of parasites (1). However, the occasional difficulty of identifying these parasite structures may decrease the sensitivity of such methods. Currently, because of these difficulties, molecular biology has been employed to detect parasites responsible for parasitic diseases (2).

Traditional parasitological analyses have the advantage of being less costly without requiring expensive reagents and equipment. Additionally, such analyses can be easily performed when a trained microscopist is available. On the other hand, molecular technology demonstrates the presence of parasites based on their antigenic components or DNA segments (3). These tests are not influenced by environmental factors that usually can interfere with the results of a stool test, for example, thus ensuring highly reliable results (4).

Current laboratory diagnostic methods for the identification of parasites include: polymerase chain reaction (PCR), random amplified polymorphic DNA (RAPD), amplified fragment length polymorphism (AFLP), restriction fragment length polymorphism (RFLP), microsatellite marker method, Luminex xMAP-based technology (areas of multianalyte profiling), loop-mediated isothermal amplification (LAMP), and the recently added real-time PCR (5-12).

The objective of the present article was to review the applications of molecular biology techniques in parasitology by evaluating and discussing their uses and benefits. 


\section{MOLECULAR METHODS FOR DETECTION OF PARASITE STRUCTURES}

Several molecular tests to detect parasites have been developed in the last decade. Their specificity and sensitivity have gradually increased, and parasites that were previously difficult to diagnose using conventional techniques began to be identified by molecular techniques. As a result, currently, these parasites can be easily treated before causing major harm to the infected population.

Next, several techniques used in molecular detection of parasites will be described.

\section{Polymerase Chain Reaction (PCR)}

The PCR makes it possible to perform selective amplification from complex genomes. This technique is based on the process of denaturing a double-stranded genomic DNA template using heat. Next, the temperature is lowered to ensure that primers can anneal to their complementary sequences into the template. Thus, the elongated DNA template follows in both directions from the primer site by means of enzymatic catalysis with a thermostable DNA polymerase, generating double-stranded products (12).

PCR-based techniques have revolutionized many areas of study because the enzymatic amplification of DNA can be performed in vitro from small amounts of material. This is particularly relevant to parasitology because it is frequently impossible to obtain or isolate a sufficient amount of material from parasites at their different life-cycle stages for conventional analysis (12). These techniques provide alternative methods for detecting specific pathogens in stool. PCR-based methods have also been combined with other techniques such as RFLP or nested PCR to genotype organisms. The detection sensitivity of PCR is higher than that of light microscopy; therefore, this technique is useful for detecting a low number of parasites in stool samples (5). The PCR technique has also been used to investigate non-intestinal parasites. The effectiveness of PCR in detecting parasite species such as Leishmania and Plasmodium has already been studied (13-22).

To detect Leishmania in clinical samples, several PCR assays have been developed (17). In studies of visceral Leishmania, PCR has been used for several purposes in addition to diagnosis, such as treatment monitoring and epidemiological studies. This technique has been described as a sensitive method for detecting Leishmania, regardless of the immune response or the patient's clinical history (23).

In relation to Plasmodium, one of the advantages of PCR in malaria detection is the significant improvement in the identification of species in mixed infections (24). The study conducted by Costa et al. (25) on malaria infection in Brazil showed that mixed infections in the Amazon region may be underestimated as a consequence of a poorly performed thick-smear technique. Therefore, the PCR method may be an important tool for diagnosing Plasmodium infection.

Despite the benefits of PCR-based technologies, such as high specificity and sensitivity to detect some parasites, the main disadvantage of these methods is that they are very time-consuming and do not provide quantitative data (26). A recent advance in PCR-based methodologies is the technique of quantitative real-time PCR (5, 26). This technique has been utilized to detect pathogens, the expression and regulation of genes, and allelic discrimination, with useful results from all these applications (26).

\section{Real-Time Polymerase Chain Reaction (RT- PCR)}

This technique was developed in the early 1990s and enables the monitoring of PCR amplification in real time. The specificity and sensitivity of the original method were maintained and combined with direct detection of the target of choice. Fluorescently labeled primers, probes or dyes are applied to a continuous collection of fluorescent signals from one or more reactions over a range of cycles. A digital camera and a fluorometer are coupled to the reaction tube in order to detect these signals. The technique has been modified to include other safer dyes (12). Currently, RTPCR enables quantification of the original sample using multiple fluorescent agents including SYBR Green dye, TaqMan probes, Förster resonance energy transfer (FRET), and Scorpion primers (27). RT-PCR is a simple, fast, closed, and automatized amplification system responsible for decreasing the risk of cross-contamination typical of conventional PCR $(28,29)$. Using RTPCR it is possible to quantify parasitic nucleic acids from environmental samples or tissues, as 
well as to estimate the intensity of infection and/ or viability of parasites (12).

In spite of the disadvantage presented by the high costs of RT-PCR, which may prevent this technique from being used in resourcepoor settings, its advantageous performance characteristics and rapid results warrant its use as a diagnostic adjunct for parasitic infection (29). Several studies have been conducted on the application of SYBR Green I RT-PCR to protozoans, including species of Cryptosporidium, Leishmania and Trypanosoma (12). The RT-PCR technique was able to detect Giardia in sewage and also proved to be a sensitive method for identifying this protozoan in samples of human feces (5). Lin et al. (26) developed a RT-PCR method to investigate Toxoplasma gondii. This test is a quick, sensitive, and quantitative technique to detect this parasite in clinical samples, and, according to the authors, is particularly useful in the diagnosis of T. gondii in AIDS patients who generally do not generate an increase in immunoglobulin $\mathrm{M}$ (IgM) or immunoglobulin G (IgG) levels. Likewise, Costa et al. (30) developed a method for detecting $T$. gondii by RT-PCR that can be useful in monitoring treatment efficacy and promoting an understanding of the pathogenesis in the reactivation of $T$. gondii infection.

Different aspects of leishmaniosis - such as diagnosis, animal models, drug efficacy and vectorial capacity - have been investigated using RT-PCR (31). Additionally, a study conducted in patients infected with Plasmodium showed that quantitative PCR may be a promising tool for monitoring antimalarial therapy (32). Using the multiplexed RT-PCR assay, Shokoples et al. (28) were able to identify the four Plasmodium species that cause infections in humans in a single reaction, even when analyzing slightly infected samples. Not only did this method reduce the cost per test, but it also allowed a rapid response, being completed in just three hours. Furthermore, it did not affect the sensitivity for the detection of simple infections.

\section{Loop-Mediated Isothermal Amplification (LAMP)}

LAMP is a method of nucleic acid amplification with extremely high sensitivity and specificity to discriminate single nucleotide differences (11). It is characterized by the use of a DNA polymerase that has low sensitivity to inhibitors and a set of four primers specially designed to recognize six different sequences on the target gene (33). Amplification occurs only when all primers bind, thus forming a product. It is a technique that can amplify a few copies of genetic material to $10^{9}$ in less than an hour (34). LAMP is a technique that enables DNA amplification with high specificity, sensitivity, and rapidity under isothermal conditions. DNA amplification can be achieved using simple incubators (water bath or block heater) because of these isothermal conditions (34). Such simple requirements make LAMP easily available for small laboratories, especially in rural endemic areas; thus, it seems to be a promising tool. This unique feature not only results in higher yields, but it also obviates the use of thermal cyclers and long cycles of varying temperatures, saving the time otherwise consumed by thermal changes. In addition, large amounts of white magnesium pyrophosphate are precipitated from DNA amplification (35). The turbidity caused by this reaction is proportional to the amount of DNA synthesized. As a consequence, it is possible to evaluate the reaction in real time by measuring the turbidity or, more importantly, by visualization by the naked eye, facilitating better distinction between positive and negative samples (36). The LAMP method can synthesize $20 \mu \mathrm{g}$ of specific DNA from $25 \mu \mathrm{L}$ of reaction mixture in one hour (35).

LAMP has already been successfully used for rapid detection of DNA and RNA viruses such as West Nile virus, severe acute respiratory syndrome (SARS), and dengue (37-39). Recently, parasitologists have adapted the LAMP technique to detect several parasitic diseases, including the human parasites Cryptosporidium, Entamoeba histolytica, Plasmodium, Trypanosoma, Taenia, Schistosoma, Fasciola hepatica and Fasciola gigantica, and Toxoplasma gondii, and animal parasites such as Theileria and Babesia $(33,36$, 40-55).

Even mosquitoes carrying the parasites Plasmodium and Dirofilaria immitis have been identified using this technique $(56,57)$. Also, this technique could detect the miracidium after the first day of exposure in snails, the intermediate hosts of Schistosoma $(48,49)$.

Nkouawa et al. (47) compared LAMP with multiplex PCR in the differential detection of Taenia in stool samples from patients with taeniasis. LAMP, with no false positives, showed 
greater sensitivity $(88.4 \%)$ than multiplex PCR (37.2\%), demonstrating a high value in detecting molecular taeniasis.

Ai et al. (50) performed DNA analysis of Fasciola sp. in mollusks that are intermediate hosts and in stool samples. The results indicated that the LAMP assay is approximately ten times more sensitive than conventional specific methods such as PCR. These findings suggest that the LAMP method for specific species may have a potential clinical application for detection and differentiation of Fasciola species, especially in endemic countries.

According to a study by Lau et al. (51), it is possible to detect Toxoplasma gondii in human blood with a sensitivity exceeding $85 \%$, which is higher than the value demonstrated using nested PCR (62.5\%), with all samples of both methods being $100 \%$ specific. Because of its simplicity, sensitivity, and specificity, LAMP is suggested as an appropriate method for the routine diagnosis of active infection in humans.

A study by Niiru et al. (45) demonstrated that the LAMP reaction can be achieved without extracting DNA from the samples. The authors found a conserved sequence in the repetitive insertion mobile element (RIME) of the subgenus Trypanozoon and used it to develop primers for a highly specific LAMP test. In 35 minutes, using a simple water bath, RIME LAMP was able to detect Trypanosoma brucei gambiense and Trypanosoma brucei rhodesiense directly from blood, serum, and cerebrospinal fluid (CSF). In a study by Matovu et al. (58), RIME LAMP was significantly more sensitive than PCR in diagnosis of the aforementioned Trypanosoma species.

Furthermore, as the LAMP method can also be applied to other areas of parasitology, other modified LAMP tests have been designed to meet specific detection needs. For example, in a study of the bovine Babesia, a multiplex LAMP (mLAMP) method was developed to simultaneously detect $B$. bovis and B. bigemina in DNA extracted from blood on filter paper (55). Likewise, Han et al. (43) implemented a LAMP assay based on $18 \mathrm{~S}$ rRNA gene for the detection of four human species of Plasmodium (falciparum, vivax, malariae, and ovale), with no DNA crossreactivity. In relation to nested PCR, LAMP had similar sensitivity, greater specificity and a faster response time. Their results are consistent with other studies that demonstrate the improvement in speed and sensitivity and specificity obtained using the LAMP assay.

\section{Luminex}

Luminex is a bead-based xMAP technology (multianalyte profiling), a system that combines flow cytometry, fluorescent microspheres (beads), lasers and digital signal processing, and is capable of simultaneously measuring up to 100 different analytes in a single sample (59). It is possible to cover each set of microsphere beads by utilizing a reagent specifically designed for a particular bioassay. This procedure enables the capturing and detection of specific analytes from a given sample. The microspheres can be covalently linked to antigens, antibodies or oligonucleotides, which serve as probes in the assay (10). Several DNA tests developed in the Luminex platform over the years have been used for identification and genotyping of bacteria, viruses and fungi such as Escherichia coli, Mycobacterium, Trichosporon, Salmonella, Listeria monocytogenes, Campylobacter jejuni, and Candida spp. (60-63). After having been adapted for parasitological surveys, Luminex can currently identify multiple organisms or different genotypes of one particular organism during the same reaction using a very low volume. This approach may prove useful in the study of antigenic diversity and for diagnosis of parasitic diseases (61).

Luminex was applied to the study of Cryptosporidium by Bandyopadhyay et al. (64). The species C. hominis and C. parvum differ genetically by a single nucleotide in the microsatellite region-2 (ML-2), which cannot be distinguished using antigen detection or serology tests. DNA sequencing is the diagnostic tool of choice; however, it is expensive, laborious, and time-consuming. Luminex is able to distinguish the species C. hominis and C. parvum in 143 DNA extractions, using oligonucleotide-specific probes for the ML-2 regions of each species, without the need for DNA sequencing. This method provides results in about five hours, being faster and less expensive than PCR followed by DNA sequencing. Luminex also proved to be $100 \%$ specific and more sensitive than direct immunofluorescence (DFA), a method routinely employed to identify species of Cryptosporidium and Giardia. In addition, DFA is not able to differentiate C. hominis from C. parvum.

Li et al. (65) allied techniques of nested PCR 
and Luminex for the diagnosis of Cryptosporidium spp., C. parvum, and Giardia duodenalis, seeking to increase sensitivity and specificity. This adapted approach proved to be $100 \%$ specific and accurate in tests of a total of 240 fecal samples.

Also in relation to the Plasmodium, the Luminex technology could detect all levels of the four human Plasmodium species (falciparum, vivax, malariae and ovale) simultaneously in blood samples (66). This study demonstrated that Luminex can improve the speed, accuracy, and reliability of other PCR methods, in addition to costing less per test than other molecular techniques.

\section{Random Amplified Polymorphic DNA (RAPD)}

Known as AP-PCR (arbitrarily primed PCR), RAPD has been extensively used for description of strains in epidemiological studies (6). The surveying of genomes of parasites is enhanced by the advantage that RAPD is a very simple, fast, and inexpensive technique that does not require either prior knowledge of the DNA sequence or DNA hybridization $(67,68)$.

In contrast with other genotyping techniques, RAPD makes use of random amplifications of the genome. The fragments are separated by gel electrophoresis and the resulting banding pattern is used in genomic profiling (6). The technique generally involves the use of primers of ten bases in a PCR protocol with low selectivity; the primers anneal to the numerous homologous sites in the genome to generate a large number of DNA fragments by the subsequent amplifications (69).

Generally, RAPD is the method used to delineate strains of microorganisms (6). Studies on parasitic nematodes of plants and humans have demonstrated its high efficiency in the differentiation of amplification profiles, as well as its ability to distinguish polymorphisms between microorganisms $(70,71)$. RAPD markers have been used to map genes for the characterization of species, to stimulate the genetic variability and determine the genetic structure of populations of different microorganisms. RAPD is particularly useful for studying the genetic structure of populations because it reveals polymorphisms in the noncoding regions of the genome (72). Studies using this technique show that it is able to differentiate species of Leishmania, in addition to being used to study polymorphisms of parasites of medical importance such as Plasmodium and Trypanosoma $(67,73)$.

In Myanmar, Thailand, and other Asian countries, this technique enabled the differentiation of endemic strains of Wuchereria bancrofti, especially at the transnational borders (68). Also, using the same technique, strains of Leishmania donovani could be distinguished in Sudan (74). In Iran, it was possible to genotype 112 isolates of Echinococcus granulosus in sheep, goats, cattle and camels (75). In Latin America, Bobes et al. (76) investigated the genetic diversity of Taenia solium in pigs in central Mexico.

\section{Amplified Fragment Length Polymorphism (AFLP)}

The AFLP technology is also a technique that allows detection of a DNA polymorphism without prior information on the sequence. This technique is highly efficient because of the possibility of analyzing a large number of bands simultaneously, with extensive coverage of the genome (77). This method of molecular diagnosis employs PCR to selectively amplify the groups of restriction fragments of totally digested genomic. It consists of four steps: DNA digestion, ligation, amplification, and gel analysis. Polymorphisms are identified based on the presence or absence of DNA fragments by polyacrylamide gel analysis (7). The advantages of this technique are the ability to search an entire genome for polymorphisms, the reproducibility of the method, and the possibility of being used against parasites about which there is no prior genetic information $(7,77,78)$.

Studies have demonstrated its application to differentiate isolates of C. parvum into two distinct genotypes, as well as strains of Leishmania belonging to cutaneous leishmaniosis (CL) and visceral leishmaniosis (VL) (7). Analysis based on AFLP polymorphic markers have revealed high genetic variability among the genome species of Leishmania major, L. tropica and L. donovani, which was sufficient to distinguish between CL and VL (79).

\section{Restriction Fragment Length Polymorphism (RFLP)}

The RFLP technique is currently one of the most commonly used molecular methods for diagnosis of species and genotypes of parasites such as Toxoplasma gondii (8). This technique was first used to detect variations at the DNA 
level (80). This reaction is based on the digestion of the PCR products by restriction enzymes or endonucleases. These enzymes cleave DNA into fragments of certain sizes, whose analysis on agarose or polyacrylamide gel results in different patterns of fragment sizes, enabling the identification (81). The RFLP technique is suitable for environmental samples because it permits the detection of multiple genotypes in the same sample (6).

A study conducted by Molloy et al. (82) in pediatric patients showed the presence of a high diversity of Cryptosporidium spp. These authors studied 1,636 children, resulting in 77 positive cases for Cryptosporidium. Of these, 34 were characterized by RFLP as Cryptosporidium hominis and 25 as C. parvum, four as C. parvum/C. hominis, and five as C. meleagridis. This study also identified five cases of Cryptosporidium rabbit genotype, three cases of Cryptosporidium cervid genotype, and one case of $C$. canis.

Importantly, the RFLP technique can also be used in the differentiation of animal parasites, such as species of Theileria in sheep. A study conducted by Zaeemi et al. (83) in Iran was able to differentiate Theileria lestoquardi, T. ovis, and T. annulata.

\section{Microsatellites}

Microsatellites are short DNA sequences (about 300 base pairs) composed of tandem repeats of one to six nucleotides, with approximately one hundred repeats (84). Microsatellites have been described in parasitology and used in some parasites of both humans and animals (9). Microsatellites are abundant in eukaryotic genomes and can mutate rapidly by loss or gain of repeat units $(81,85)$. The wide variety of applications of microsatellites is mainly because they show frequent polymorphism, codominant inheritance, high reproducibility and high resolution, require simple typing methods, and can be detected by PCR (84).

Despite their potential usefulness, microsatellite markers were developed only for some parasitic nematodes such as species of Trichostrongyloid nematodes (9). The low popularity of these genetic markers may be explained by the high number of microsatellites, which cause technical difficulties in isolating parasites by PCR $(9,85)$.

\section{CONCLUDING REMARKS}

The efficient control of mortality in parasitic diseases is ensured by the administration of single-dose drugs to patients with severe infections, which are easily detected by means of traditional methods (86). Simultaneously, there is a mortality rate among infected individuals who are not sensitive to traditional diagnostic methods, causing the need for more sensitive and efficient diagnostic methods. In order to overcome the limitation of these tests, molecular assays have been developed.

Studies have shown that molecular assays are highly effective and sensitive for the detection of parasitic infections, regardless of the type of infection and the submitted sample. These tests can also be used in studies of animal models, drug efficacy, and vectorial capacity (31). Among the various techniques available, some methods stand out for being applicable not only to diagnosis and differentiation of species, but also to treatment monitoring, and thus have become a promising tool to aid in clinical diagnosis.

In addition to being highly specific and sensitive, molecular assays seem to be promising substitutes for direct microscopy, although the latter method is still considered the "gold standard" for identifying parasites.

Another important aspect of molecular methods is their applicability to epidemiological studies, because such studies involve genetic diversity of populations and geographical distribution of parasitic diseases, susceptibility to infections and possible mutations, besides correlation between hosts and clinical manifestations, thus enabling a better understanding of the behavior of a disease among a given population.

Although high cost is still a limiting factor for the use of molecular techniques, these tests are increasingly being used in clinical diagnosis, treatment monitoring, and epidemiological studies of parasitic diseases affecting people worldwide. Their use provides detailed knowledge on the morphology, genetic characteristics and behavior of parasitic disease in the affected populations.

\section{COPYRIGHT \\ (c) CEVAP 2011}




\section{SUBMISSION STATUS}

Received: November 24, 2011.

Accepted: April 4, 2011.

Abstract published online: April 6, 2011.

Full paper published online: August 31, 2011.

\section{CONFLICTS OF INTEREST}

There is no conflict.

\section{CORRESPONDENCE TO}

REJANE GIACOMELLI TAVARES, Instituto de Ciências da Saúde, RS 239, 2755, Novo Hamburgo, RS, 93352-000, Brasil. Phone: +55 51 3586 9019. Fax: +55 513589 9000. Email: tavares. rejane@gmail.com.

\section{REFERENCES}

1. Kompalic-Cristo A, Britto C, Fernandes O. Diagnóstico molecular da toxoplasmose. J Bras Patol Med Lab. 2005;41(4):229-35.

2. Jardim EAGV, Linhares GFC, Torres FAG, Araújo JLB, Barbosa SM. Diferenciação específica entre Taenia saginata e Taenia solium por ensaio de PCR e duplexPCR. Ciênc Rural. 2006;36(1):166-72.

3. Scott JA. The molecular genetics of resistance: resistance as a response to stress. Florida Entomologist. 1995;78(3):399-414.

4. Portela-Lindoso AAB, Shikanai-Yasuda MA. Doença de Chagas crônica: do xenodiagnóstico e hemocultura à reação em cadeia da polimerase. Rev Saúde Pública. 2003;37(1):107-15.

5. Guy RA, Xiao C, Horgen PA. Real-time PCR assay for detection and genotype differentiation of Giardia lamblia in stool specimens. J Clin Microbiol. 2004;42(7):3317-20.

6. Monis PT, Andrews RH. Molecular epidemiology: assumptions and limitations of commonly applied methods. Int J Parasitol. 1998;28(6):981-7.

7. Blears MJ, Pokorny NJ, Carreno RA, Chen S, De Grandis SA, Lee $\mathrm{H}$, et al. DNA fingerprinting of Cryptosporidium parvum isolates using amplified fragment length polymorphism (AFLP). J Parasitol. 2000;86(4):838-41.

8. Quan JH, Kim TY, Choi IU, Lee YH. Genotyping of a Korean isolate of Toxoplasma gondii by multilocus PCR-RFLP and microsatellite analysis. Korean J Parasitol. 2008;46(2):105-8.

9. Temperley ND, Webster LM, Adam A, Keller LF, Johnson PC. Cross-species utility of microsatellite markers in Trichostrongyloid nematodes. J Parasitol. 2009;95(2):487-9.

10. Dunbar SA. Applications of Luminex xMAP technology for rapid, high-throughput multiplexed nucleic acid detection. Clin Chim Acta. 2006;363(1-2):71-82.

11. Parida M, Sannarangaiah S, Dash PK, Rao PV, Morita K. Loop mediated isothermal amplification (LAMP): a new generation of innovative gene amplification technique; perspectives in clinical diagnosis of infectious diseases. Rev Med Virol. 2008;18(6):407-21.

12. Gasser RB. Molecular tools - advances, opportunities and prospects. Vet Parasitol. 2006;136(2):69-89.

13. Piarroux R, Gambarelli F, Dumon H, Fontes M, Dunan S, Mary C, et al. Comparison of PCR with direct examination of bone marrow aspiration, myeloculture, and serology for diagnosis of visceral Leishmaniasis in immunocompromised patients. J Clin Microbiol. 1994;32(3):746-9.

14. Osman OF, Oskam L, Zijlstra EE, Kroon NC, Schoone GJ, Khalil ET, et al. Evaluation of PCR for diagnosis of visceral leishmaniasis. J Clin Microbiol. 1997;35(10):2454-7.

15. Harris E, Kropp G, Belli A, Rodriguez B, Agabian N. Single-step multiplex PCR assay for characterization of new world Leishmania complexes. J Clin Microbiol. 1998;36(7):1989-95.

16. Lachaud L, Dereure J, Chabbert E, Reynes J, Mauboussin JM, Oziol E, et al. Optimized PCR using patient blood samples for diagnosis and follow-up of visceral Leishmaniasis, with special reference to AIDS patients. J Clin Microbiol. 2000;38(1):236-40.

17. Andrade BB, Boaventura V, Barral-Netto M, Barral A. Métodos diagnósticos da leishmaniose tegumentar: fatos, falácias e perspectivas. Gaz Méd Bahia. 2005;75(1):75-82.

18. Antinori S, Calattini S, Longhi E, Bestetti G, Piolini $\mathrm{R}$, Magni $\mathrm{C}$, et al. Clinical use of polymerase chain reaction performed on peripheral blood and bone marrow samples for the diagnosis and monitoring of visceral Leishmaniasis in HIV-infected and HIVuninfected patients: a single-center, 8-year experience in Italy and review of the literature. Clin Infect Dis. 2007;44(12):1602-10.

19. Wooden J, Kyes S, Sibley CH. PCR and strain identification in Plasmodium falciparum. Parasitol Today. 1993;9(8):303-5.

20. Contamin H, Fandeur T, Bonnefoy S, Skouri F, Ntoumi F, Mercereau-Puijalon O. PCR typing of field isolates of Plasmodium falciparum. J Clin Microbiol. 1995;33(4):944-51.

21. Roper C, Elhassan IM, Hviid L, Giha H, Richardson W, Babiker $\mathrm{H}$, et al. Detection of very low level Plasmodium falciparum infections using the nested polymerase chain reaction and a reassessment of the epidemiology of unstable malaria in Sudan. Am J Trop Med Hyg. 1996;54(4):325-31.

22. Duraisingh MT, Curtis J, Warhurst DC. Plasmodium falciparum: detection of polymorphisms in the dihydrofolate reductase and dihydropteroate synthetase genes by PCR and restriction digestion. Exp Parasitol. 1998;89(1):1-8.

23. Gontijo CMF, Melo MN. Leishmaniose visceral no Brasil: quadro atual, desafios e perspectivas. Rev Bras Epidemiol. 2004;7(3):338-49.

24. Hänscheid T. Diagnosis of malaria: a review of alternatives to conventional microscopy. Clin Lab Haematol. 1999;21(4):235-45.

25. Costa MRF, Vieira PPR, Ferreira CO, Lacerda MVG, Alecrim WD, Alecrim MGC. Diagnóstico molecular da malária em uma unidade de atenção terciária 
na Amazônia Brasileira. Rev Soc Bras Med Trop. 2008;41(4):381-5.

26. Lin MH, Chen TC, Kuo TT, Tseng CC, Tseng CP. Realtime PCR for quantitative detection of Toxoplasma gondii. J Clin Microbiol. 2000;38(11):4121-5.

27. Ndao M. Diagnosis of parasitic diseases: old and new approaches. Interdiscip Perspect Infect Dis. 2009;2009:1-15.

28. Shokoples SE, Ndao M, Kowalewska-Grochowska K, Yanow SK. Multiplexed real-time PCR assay for discrimination of Plasmodium species with improved sensitivity for mixed infections. J Clin Microbiol. 2009;47(4):975-80.

29. Farcas GA, Soeller R, Zhong K, Zahirieh A, Kain KC. Real-time polymerase chain reaction assay for the rapid detection and characterization of chloroquineresistant Plasmodium falciparum malaria in returned travelers. Clin Infec Dis. 2006;42(5):622-7.

30. Costa JM, Pautas C, Ernault P, Foulet F, Cordonnier C, Bretagne S. Real-time PCR for diagnosis and followup of Toxoplasma reactivation after allogeneic stem cell transplantation using fluorescence resonance energy transfer hybridization probes. J Clin Microbiol. 2000;38(8):2929-32.

31. Talmi-Frank D, Nasereddin A, Schnur LF, Schönian G, Töz SO, Jaffe CL, et al. Detection and identification of old world Leishmania by high resolution melt analysis. PLoS Negl Trop Dis. 2010;4(1):e581.

32. Rougemont M, Van Saanen M, Sahli R, Hinrikson HP, Bille J, Jaton K. Detection of four Plasmodium species in blood from humans by $18 \mathrm{~S}$ rRNA gene subunitbased and species-specific real-time PCR assays. J Clin Microbiol. 2004;42(12):5636-43.

33. Paris DH, Imwong M, Faiz AM, Hasan M, Yunus $\mathrm{EB}$, Silamut K, et al. Loop-mediated isothermal PCR (LAMP) for the diagnosis of falciparum malaria. Am J Trop Med Hyg. 2007;77(5):972-6.

34. Notomi T, Okayama H, Masubuchi H, Yonekawa $\mathrm{T}$, Watanabe $\mathrm{K}$, Amino $\mathrm{N}$, et al. Loop-mediated isothermal amplification of DNA. Nucleic Acids Res. 2000;28(12):E63.

35. Mori Y, Nagamine K, Tomita N, Notomi T. Detection of loop-mediated isothermal amplification reaction by turbidity derived from magnesium pyrophosphate formation. Biochem Biophys Res Commun. 2001;289(1):150-4.

36. Nkouawa A, Sako Y, Nakao M, Nakaya K, Ito A. Loop-mediated isothermal amplification method for differentiation and rapid detection of Taenia species. J Clin Microbiol. 2009;47(1):168-74.

37. Parida M, Posadas G, Inoue S, Hasebe F, Morita K. Real-time reverse transcription loop-mediated isothermal amplification for rapid detection of West Nile virus. J Clin Microbiol. 2004;42(1):257-63.

38. Poon LL, Wong BW, Chan KH, Ng SS, Yuen KY, Guan $Y$, et al. Evaluation of real-time reverse transcriptase PCR and real-time loop-mediated amplification assays for severe acute respiratory syndrome coronavirus detection. J Clin Microbiol. 2005;43(7):3457-9.

39. Parida $M$, Horioke $K$, Ishida $H$, Dash PK, Saxena $P$, Jana AM, et al. Rapid detection and differentiation of dengue virus serotypes by a real-time reverse transcription-loop-mediated isothermal amplification assay. J Clin Microbiol. 2005;43(6):2895-903.

40. Bakheit MA, Torra D, Palomino LA, Thekisoe OM, Mbati PA, Ongerth J, et al. Sensitive and specific detection of Cryptosporidium species in PCRnegative samples by loop-mediated isothermal DNA amplification and confirmation of generated LAMP products by sequencing. Vet Parasitol. 2008;158(12):11-22.

41. Liang SY, Chan YH, Hsia KT, Lee JL, Kuo MC, Hwa $\mathrm{KY}$, et al. Development of loop-mediated isothermal amplification assay for detection of Entamoeba histolytica. J Clin Microbiol. 2009;47(6):1892-5.

42. Poon LLM, Wong BWY, Ma EHT, Chan KH, Chow LMC, Abeyewickreme W, et al. Sensitive and inexpensive molecular test for falciparum malaria: defecting Plasmodium falciparum DNA directly from heat - treated blood by loop-mediated isothermal amplification. Clin Chem. 2006;52(2):303-6.

43. Han ET, Watanabe R, Sattabongkot J, Khuntirat B, Sirichaisinthop J, Iriko $\mathrm{H}$, et al. Detection of four Plasmodium species by genus- and species-specific loop-mediated isothermal amplification for clinical diagnosis. J Clin Microbiol. 2007;45(8):2521-8.

44. Pöschl B, Waneesorn J, Thekisoe O, Chutipongvivate S, Karanis P. Comparative diagnosis of malaria infections by microscopy, nested PCR, and LAMP in northern Thailand. Am J Trop Med Hyg. 2010;83(1):56-60.

45. Njiru ZK, Mikosza ASJ, Matovu E, Enyaru JCK, Ouma JO, Kibona SN, et al. African trypanosomiasis: sensitive and rapid detection of the sub-genus Trypanozoon by loop-mediated isothermal amplification (LAMP) of parasite DNA. Int J Parasitol. 2008;38(5):589-99.

46. Kuboki N, Inoue N, Sakurai T, Di Cello F, Grab DJ, Suzuki $\mathrm{H}$, et al. Loop-mediated isothermal amplification for detection of African trypanosomes. J Clin Microbiol. 2003;41(12):5517-24.

47. Nkouawa A, Sako Y, Li T, Chen X, Wandra T, Swastika IK, Nakao M, et al. Evaluation of a loopmediated isothermal amplification method using fecal specimens for differential detection of Taenia species from humans. J Clin Microbiol. 2010;48(9):3350-2.

48. Kumagai T, Furushima-Shimogawara R, Ohmae $\mathrm{H}$, Wang TP, Lu S, Chen R, et al. Detection of early and single infections of Schistosoma japonicum in the intermediate host snail, Oncomelania hupensis, by PCR and loop-mediated isothermal amplification (LAMP) assay. Am J Trop Med Hyg. 2010;83(3):542-8.

49. Abbasi I, King $\mathrm{CH}$, Muchiri EM, Hamburger J. Detection of Schistosoma mansoni and Schistosoma haematobium DNA by loop-mediated isothermal amplification: identification of infected snails from early prepatency. Am J Trop Med Hyg. 2010;83(2):42732.

50. Ai L, Li C, Elsheikha HM, Hong SJ, Chen JX, Chen $\mathrm{SH}$, et al. Rapid identification and differentiation of Fasciola hepatica and Fasciola gigantica by a loopmediated isothermal amplification (LAMP) assay. Vet Parasitol. 2010;174(3-4):228-33.

51. Lau YL, Meganathan P, Sonaimuthu P, Thiruvengadam 
G, Nissapatorn V, Chen Y. Specific, sensitive, and rapid diagnosis of active toxoplasmosis by a loop-mediated isothermal amplification method using blood samples from patients. J Clin Microbiol. 2010;48(10):3698-702.

52. Alhassan A, Thekisoea OM, Yokoyamaa N, Inouea N, Motloangb MY, Mbati PA, et al. Development of loopmediated isothermal amplification (LAMP) method for diagnosis of equine piroplasmosis. Vet Parasitol. 2007;143(2):155-60.

53. Wang LX, He L, Fang R, Song QQ, Tu P, Jenkins A, et al. Loop-mediated isothermal amplification (LAMP) assay for detection of Theileria sergenti infection targeting the p33 gene. Vet Parasitol. 2010;171(12):159-62.

54. Guan G, Chauvin A, Luo J, Inoue N, Moreau E, Liu $Z$, et al. The development and evaluation of a loopmediated isothermal amplification (LAMP) method for detection of Babesia spp. infective to sheep and goats in China. Exp Parasitol. 2008;120(1):39-44.

55. Iseki H, Alhassan A, Ohta N, Thekisoe OM, Yokoyama $\mathrm{N}$, Inoue $\mathrm{N}$, et al. Development of a multiplex loopmediated isothermal amplification (mLAMP) method for the simultaneous detection of bovine Babesia parasites. J Microbiol Methods. 2007;71(3):281-7.

56. Aonuma H, Suzuki M, Iseki H, Perera N, Nelson B, Igarashi I, et al. Rapid identification of Plasmodiumcarrying mosquitoes using loop-mediated isothermal amplification. Biochem Biophys Res Commun. 2008;376(4)671-6.

57. Aonuma H, Yoshimura A, Perera N, Shinzawa N, Bando $\mathrm{H}$, Oshiro S, et al. Loop-mediated isothermal amplification applied to filarial parasites detection in the mosquito vectors: Dirofilaria immitis as a study model. Parasit Vectors. 2009;2(1):15.

58. Matovu E, Kuepfer I, Boobo A, Kibona S, Burri C. Comparative detection of trypanosomal DNA by loop-mediated isothermal amplification and PCR from flinders technology associates cards spotted with patient blood. J Clin Microbiol. 2010;48(6):2087-90.

59. Luminex Corporation [Internet]. In: xMAP Technology. [cited 2010 Jun 01] Available from: http:// www.luminexcorp.com.

60. Dunbar SA, Vander Zee CA, Oliver KG, Karem KL, Jacobson JW. Quantitative, multiplexed detection of bacterial pathogens: DNA and protein applications of the Luminex LabMAP system. J Microbiol Methods. 2003;53(2):245-52.

61. Cowan LS, Diem L, Brake MC, Crawford JT. Transfer of a Mycobacterium tuberculosis genotyping method, spoligotyping, from a reverse line-blot hybridization, membrane-based assay to the Luminex multianalyte profiling system. J Clin Microbiol. 2004;42(1):474-7.

62. Diaz MR, Fell JW. High-throughput detection of pathogenic yeasts of the genus Trichosporon. J Clin Microbiol. 2004;42(8):3696-706.

63. Das S, Brown TM, Kellar KL, Holloway BP, Morrison CJ. DNA probes for the rapid identification of medically important Candida species using a multianalyte profiling system. FEMS Immunol Med Microbiol. 2006;46(2):244-50.

64. Bandyopadhyay K, Kellar KL, Moura I, Casaqui
Carollo MC, Graczyk TK, Slemenda S, et al. Rapid microsphere assay for identification of Cryptosporidium hominis and Cryptosporidium parvum in stool and environmental samples. J Clin Microbiol. 2007;45(9):2835-40.

65. Li W, Zhang N, Gong P, Cao L, Li J, Su L, et al. A novel multiplex PCR coupled with Luminex assay for the simultaneous detection of Cryptosporidium spp., Cryptosporidium parvum and Giardia duodenalis. Vet Parasitol. 2010;173(1-2):11-8.

66. McNamara DT, Kasehagen LJ, Grimberg BT, ColeTobian J, Collins WE, Zimmerman PA. Diagnosing infection levels of four human malaria parasite species by a polymerase chain reaction/ligase detection reaction fluorescent microsphere-based assay. Am J Trop Med Hyg. 2006;74(3):413-21.

67. Alimoradi S, Hajjaran H, Mohebali M, Mansouri F. Molecular identification of Leishmania species isolated from human cutaneous leishmaniasis by RAPD-PCR. Iranian J Publ Health. 2009;38(2):44-50.

68. Nuchprayoon S, Junpee A, Poovorawan Y. Random Amplified Polymorphic DNA (RAPD) for differentiation between Thai and Myanmar strains of Wuchereria bancrofti. Filaria J. 2007;6(1):6

69. Lupchinski JR E, Vargas L, Ribeiro RP, Moreira HLM, Valentim M, Povh JA. A importância da utilização da técnica RAPD para a identificação de dactilogirídeos em tilápias do Nilo. (Oreochromis niloticus). Arq Cienc Vet Zool Unipar. 2006;9(1):49-57.

70. Jobet E, Bougnoux ME, Morand S, Rivault C, Cloarec A, Hugot JP. Use of random amplified polymorphic DNA (RAPD) for generating specific DNA probes for oxyuroid species (Nematoda). Parasite. 1998;5(1):4750.

71. Martinez EM, Correia JA, Villela EV, Duarte AN, Ferreira LF, Bello AR. Random amplified polymorphic DNA analysis of DNA extracted from Trichuris trichiura (Linnaeus, 1771) eggs and its prospective application to paleoparasitological studies. Mem Inst Oswaldo Cruz. 2003;98 Suppl 1:59-62.

72. Jain SK, Neekhra B, Pandey D, Jain K. RAPD marker system in insect study: a review. Indian J Biotechnol. 2010;9(1):7-12.

73. Hajjaran H, Mohebali M, Razavi MR, Rezaei S, Kazemi B, Edrissian GhH. Identification of Leishmania species isolated from human cutaneous Leishmaniasis, using Random Amplified Polymorphic DNA (RAPD-PCR). Irian J Publ Health. 2004;33(4):8-15.

74. Hamad SH, Khalil EA, Musa AM, Ibrahim ME, Younis $\mathrm{BM}$, Elfaki ME, et al. Leishmania donovani: genetic diversity of isolates from Sudan characterized by PCRbased RAPD. Exp Parasitol. 2010;125(4):389-93.

75. Sharbatkhori M, Mirhendi H, Harandi MF, Rezaeian M, Mohebali M, Eshraghian M, et al. Echinococcus granulosus genotypes in livestock of Iran indicating high frequency of G1 genotype in camels. Exp Parasitol. 2010;124(4):373-9.

76. Bobes RJ, Fragoso G, Reyes-Montes Mdel R, DuarteEscalante E, Vega R, de Aluja AS, et al. Genetic diversity of Taenia solium cysticerci from naturally infected pigs of central Mexico. Vet Parasitol. 2010;168(1-2):130-5. 
77. Buttow MV, Castro CM, Schwartz E, Tonietto A, Barbieri RL. Caracterização molecular de populações de Butia capitata (Arecaceae) do Sul do Brasil através de marcadores AFLP. Rev Bras Frutic. 2010;32(1):2309.

78. Bonin A, Ehrich D, Manel S. Statistical analysis of amplified fragment length polymorphism data: a toolbox for molecular ecologists and evolutionists. Mol Ecol. 2007;16(18):3737-58.

79. Kumar A, Boggula VR, Misra P, Sundar S, Shasany AK, Dube A. Amplified fragment length polymorphism (AFLP) analysis is useful for distinguishing Leishmania species of visceral and cutaneous forms. Acta Trop. 2010;113(2):202-6.

80. Carpentieri-Pípolo V, Gallo-Meagher M, Dickson DW, Gorbet DW, Mendes ML, de Souza SGH. Comparação entre métodos de marcação da sonda de RFLP R2430E utilizada na seleção de cultivares de amendoim resistente à Meloidogyne arenaria. Ciênc Agrár. 2008;29(4):783-8.

81. Huber F. Caracterização genotípica e estudo filogenético de Cryptosporidium spp. obtidos de diferentes hospedeiros [dissertation]. Rio de Janeiro: Universidade Federal Rural do Rio de Janeiro; 2007. 72p.
82. Molloy SF, Smith HV, Kirwan P, Nichols RA, Asaolu SO, Connelly L, et al. Identification of a high diversity of Cryptosporidium species genotypes and subtypes in a pediatric population in Nigeria. Am J Trop Med Hyg. 2010;82(4):608-13.

83. Zaeemi M, Haddadzadeh H, Khazraiinia P, Kazemi B, Bandehpour M. Identification of different Theileria species (Theileria lestoquardi, Theileria ovis, and Theileria annulata) in naturally infected sheep using nested PCR-RFLP. Parasitol Res. 2011;108(4):83743.

84. Oliveira EJ, Pádua JG, Zucchi MI, Vencovsky R, Vieira MLC. Origin evolution and genome distribution of microsatellites. Genet Mol Biol. 2006;29(2):294-307.

85. Johnson PC, Webster LM, Adam A, Buckland R, Dawson DA, Keller LF. Abundant variation in microsatellites of the parasitic nematode Trichostrongylus tenuis and linkage to a tandem repeat. Mol Biochem Parasitol. 2006;148(2):210-8.

86. Gomes LI, Dos Santos Marques LH, Enk MJ, de Oliveira MC, Coelho PM, Rabello A. Development and evolution of sensitive PCR-ELISA System for detection of Schistosoma infection in feces. PLoS Negl Trop Dis. 2010;4(4):e664. 